\title{
CORRECTION
}

View Article Online

View Journal I View Issue

D) Check for updates

Cite this: J. Mater. Chem. A, 2017, 5, 17089

DOI: 10.1039/c7ta90167d

www.rsc.org/MaterialsA

\section{Correction: Crystalline In-Sb-S framework for highly-performed lithium/sodium storage}

Lina Nie, $+^{\mathrm{ab}}$ Jian Xie, $+^{\mathrm{b}}$ Guangfeng Liu, ${ }^{\mathrm{b}}$ Shiji Hao, ${ }^{\mathrm{b}}$ Zhichuan J. Xu, ${ }^{\mathrm{b}}$ Rong Xu ${ }^{\mathrm{c}}$ and Qichun Zhang*bd

Correction for 'Crystalline In-Sb-S framework for highly-performed lithium/sodium storage' by Lina Nie et al., J. Mater. Chem. A, 2017, 5, 14198-14205.

The authors wish to add a $\$$ symbol after the author name Jian Xie to note that they are an equal main contributor to the article along with Lina Nie.

The Royal Society of Chemistry apologises for these errors and any consequent inconvenience to authors and readers. 